\title{
Supplementation of Adilo Sheep with Sole or Mixtures of Moringa stenopetala Leaf Meal and Wheat Bran on Feed intake, Body Weight Gain and Digestibility
}

\author{
Hagos Arefaine $^{1^{*}}$ and Solomon Melaku ${ }^{2}$
}

Received: $18^{\text {th }}$ August 2016 / Accepted: $3^{\text {rd }}$ February 2017

\begin{abstract}
The Objective of this study was to evaluate the effect of supplementation with Moringa stenopetala leaf meal (MSLM), wheat bran (WB) and the mixture on feed intake, nutrient digestibility, and body weight gain of Adilo sheep. A total of twenty five, one year old, intact male adilo sheep having initial body weights $(B W)$ of $17.64 \pm 0.61 \mathrm{~kg}$ (mean $\pm S D)$ were used. Before starting the experiment, sheep were adapted for 14 days. During this period, all animals were adapted with treatment diets and treated against common diseases in the area. Sheep were blocked into 5 based on their initial $B W$ then five sheep were randomly assigned to one of the five treatments. The $B W \pm S D$ of block $4,1,5$ and 3 were $17.03 \pm 0.41,17.25 \pm 0.33,17.5 \pm 0.60,17.7 \pm 0.19$ and $18.01 \pm 0.24 \mathrm{~kg}$, respectively. The treatment feeds were adlibitum feeding of Rhodes grass hay alone (T1) or with daily supplementation of $300 \mathrm{~g}$ dry matter (DM) sole MSLM (T2), 2MSLM:1 WB mix (T3), IMSLM:2WB mix (T4) and sole WB (T5). The data on nutrient content, feed intake, body weight gain, and digestibility were analyzed using Proc Mixed procedure SAS (SAS Institute, USA, version 9.4). The model included treatment as fixed factor, while experimental animals were included as a random factor. The crude protein content, total dry matter intake (DMI) and apparent nutrient digestibility were lower $(P<0.001)$ in sheep fed non-supplemented diet than the supplemented diets. Among the supplement diets, a higher DMI $(P<0.001)$ was observed in sheep fed T2 compared to sheep fed with T3, T4, and T5 diets. The higher $(P<05)$ apparent digestibility of DM and CP in supplemented sheep could be attributed to the higher protein and lower fiber content of the supplement diets. Apart from this, sheep fed non-supplement diet lost weight by 7.8 g/head/day whereas, sheep fed diets supplemented with T2, T3, T4 and T5 gained 71.1, 51.5, 46.7 and $44.4 \mathrm{~g} /$ head/day, respectively. Among the supplemented group, significantly higher $(P<0.001)$ daily $B W$ gain, final $B W$ and feed conversion efficiency were recorded in sheep fed on T2 than T3, T4 and T5. Hence, sheep producers can apply $T 2$ to get better nutrient utilization, growth rate and market weight.
\end{abstract}

Keywords: Adilo sheep, Feeding trial, Digestibility trial, Feed conversion efficiency

\section{INTRODUCTION}

Ethiopian economy is based mainly on agriculture and the major agricultural products includes cereal crops, pulses, coffee, oil seeds, hide and skins, live cattle, goat and sheep (Markos, 2006). According to CSA (2011), the total sheep population in Ethiopia is about 25.5 million. However beside the huge population, the reproductive and productive performance

of sheep is appeared low. Poor quality and quantity of feed is among the factors which limit their productivity. According to CTA (1991), the dietary nutrients, especially protein and energy are the major limiting factors affecting productivity of sheep.

In most part of the country, native pasture and the crop residues are the major livestock feed 
resources. However, the quantity and quality of feed produced is known to be affected by the season, beside to this, communal grazing lands are also overgrazed (ILCA, 1988). Bake and Hansen (1987) reported that the crude protein content of most of the roughage feed in the country is less than $7 \%$ which is below their maintenance requirement. As a result, the sheep stay longer time to acquire slaughter weight (Nega and Melaku, 2009). According to Abebaw and Solomon (2008), supplementation with agro-industrial byproducts such as oilseed cakes and cereal bran promote feed intake as well as growth performance in sheep. However, in most part of the country, the use of such supplement feed in sheep diet is not common. This is due mainly to their limited availability and higher price. Beside this, some oil seed cakes like peanut seed cake, sesame seed cake, linseed cake and cotton seed cake contain antinutritional factors which may lead to health hazard unless they are properly treated before being fed (McDonald et al., 2002). Therefore, the use of leaves of multipurpose tree like Moringa stenopetala as a protein supplement has been suggested as a substitute to use of agroindustrial byproducts. Moringa stenopetala is a non-leguminous multipurpose tree, grown around home boundary, and feeding of the vegetative parts of the plant leaves are likely to be of greatest significance. The potential for these by-products feeding is great due to its high protein content and its low tannin content $[<14$ $\mathrm{g} / \mathrm{kg}$ dry matter (DM)] (Makkar and Becker, 1996). However, presently this foliage is not widely utilized as an animal feed. Hence, the objective of this experiment was to evaluate the replacement value of wheat bran (WB) by different level of Moringa stenopetala leaf meal (MSLM) on dry matter intake (DMI), apparent nutrient digestibility and weight gain (WG) of Adilo sheep fed on grass hay.

\section{MATERIALS AND METHODS}

\section{Description of the Study Area, Experimental Animals and Management}

The experiment was conducted at Arba Minch University which is found in Southern Nations and Nationality Peoples Regional State of Gamo Gofa Zone in Ethiopia. The study area is located at $505 \mathrm{~km}$ from South of Addis Ababa, at an altitude of 1284 masl and between $6^{\circ} 1^{\prime} 60$ $\mathrm{N}$ latitude and $37^{\circ} 32^{\prime} 60 \mathrm{E}$ longitude.

Twenty five $(\mathrm{n}=25)$ yearling male Adilo sheep with initial body weights (BW) of $17.64 \pm$ 0.61 (mean \pm SD) were purchased from a local market of Wolyta soda. The sheep were then quarantined for 15 days and de-wormed using Ivermectin against to internal and external parasites. The experimental animals were sprayed with Diazenon against to external parasites. The experimental animals were also vaccinated against to anthrax and pasteurellosis which are the most common sheep diseases of the area. All medical treatment was conducted by well experienced veterinarian.

\section{Feed Preparation and Treatments}

Grass hay collected from the University farm was stored under a shade to maintain its quality and was used as the control treatment throughout the experimental period. Moringa stenopetala leave were first collected from the university farm then air dried, grind and stored. Wheat bran was purchased from Adama animal feed processing factory. The ration for the entire experimental period was formulated comprising different proportion of MSLM and WB. A randomized complete block design (RCBD) was applied to this experiment. Based on their initial body weights, sheep were grouped in to five blocks (5 sheep/block/treament) and the $\mathrm{BW} \pm \mathrm{SD}$ of block $4,1,5$ and 3 were $17.03 \pm$ $0.41,17.25 \pm 0.33,17.5 \pm 0.60,17.7 \pm 0.19$ and $18.01 \pm 0.24 \mathrm{~kg}$, respectively. (Table 01) 
Table 01: Composition of test feed fed to Adilo sheep during the experiment

\begin{tabular}{ccccc}
\hline Treatment & Gras Hay & MSLM $(\mathrm{g})$ & WB $(\mathrm{g})$ & $\begin{array}{c}\text { Total supplement } \\
\text { offered }(\mathrm{g})\end{array}$ \\
\hline T1 & adlibitum & - & - & - \\
T2 & adlibitum & 300 & - & 300 \\
T3 & adlibitum & 200 & 100 & 300 \\
T4 & adlibitum & 100 & 200 & 300 \\
T5 & adlibitum & - & 300 & 300 \\
\hline
\end{tabular}

MSLM: Moringa stenopetala leaf meal; WB: Wheat bran; MSLM WB: mixture of Moringa stenopetala leaf meal and wheat bran. DM: Dry matter. T1: adlibitum grass hay; T2: adlibitum grass hay + 300g DM MSLM; T3: adlibitum grass hay + 200g DM MSLM + 100g DM WB; T4: adlibitum grass hay + 100g DM MSLM + 200g DM WB; T5: ad libitum grass hay + 300g DM WB.

\section{Feeding Trial}

Feed intake and the BW gain were recorded for the last 90 days. During this period, grass hay was offered ad labium, where the supplement mix were given at 08:00h and 16:00h daily. The amount of daily feed offered and the amount refused were measured during the entire experimental period to determine the feed intake of the control and the supplement feeds. Daily feed intake was determined by the subtracting the amount of refusal from feed offered and the initial BW of each sheep were determined by taking average of two consecutive weights after overnight fasting. The BW gain of the animals was then measured at ten days interval after over-night fasting and mean daily BW gain was calculated by regressing BW measurements on days of feeding.

Feed conversion efficiency $(\mathrm{FCE})=$ Amount of feed consumed Body weight change

\section{Digestibility Trial}

A digestibility trial was conducted at the end of 90 days of feeding trial. Sheep were adapted for 3 days with fecal collection bag followed by 7 days of feces sample collection. The amount of faces collected per sheep per day was weighed and $20 \%$ was sub-sampled and stored frozen at $-20{ }^{\circ} \mathrm{C}$. At the end of 7 days fecal collection period, fecal sample of individual sheep was pooled, mixed, sub-sampled $(20 \%)$ and dried at $60{ }^{\circ} \mathrm{C}$ for 24 hours. The apparent nutrient digestibility (AND) of dry matter (DM), crude protein $(\mathrm{CP})$, organic matter $(\mathrm{OM})$, neutral detergent fiber (NDF), acid detergent fiber (ADF) and acid detergent lignin (ADL) were determined as follows:

Apparent Nutrient Digestibility (AND) \%= (Nutrient in feed offered - nutrient in faeces x 100) Nutrient in feed offered

\section{Chemical Analysis}

Sub-samples of the feed offered, refused as well as feces were taken to Debrezeit Nutrition laboratory for DM, OM, CP and analysis of ash content using the procedure of AOAC (1990). The fiber (NDF, ADF and ADL) fractions of feed and faeces were determined by following the procedure described in Van Soest (1994). The CP content was estimated as nitrogen $\times 6.25$.

\section{Statistical Analysis}

The analyses of variance (ANOVA) of feed intake, BW gain and ANDC were run using the general linear model (SAS, 2004). Least significant difference (LSD) was used to identify the differences among treatments means. The analysis of variance model used for intake, weight gain and digestibility was $\mathrm{Yij}=\mu+\mathrm{Ti}$ $+\mathrm{Bj}+$ eij, where, $\mathrm{Yij}=$ response variable in $\mathrm{i}^{\text {th }}$ treatment and $\mathrm{j}^{\text {th }}$ block, $\mu=$ overall mean, $\mathrm{T}_{\mathrm{i}}=$ $\mathrm{i}^{\text {th }}$ treatment effect, $\mathrm{B}_{\mathrm{j}}=\mathrm{j}^{\text {th }}$ block effect, and $\mathrm{e}_{\mathrm{ij}}=$ random error. 


\section{RESULTS}

\section{Nutrient Composition of Experimental Feed}

Grass hay used in this study contained comparatively lower CP (527 g/kg DM) and higher NDF, ADF and ADL content than all test feed. (Table 02). Of the supplemented feed, MSLM contained higher CP content than WB and mixtures of MSLM and WB, whereas the NDF, ADF and ADL content of WB was the highest compared with the MSLM and mixtures of MSLM and WB. The hay refusal contained less $\mathrm{CP}$ and higher cell wall fractions than the hay offered and the refusals contained less leaf to stem ratio, due to selective eating behavior of sheep.

\section{Feed Intake}

Hay DM intake was higher $(\mathrm{P}<0.001)$ for sheep fed T1 compared with those fed on supplemented treatments (T2, T3, T4 and T5)
(Table 03), while the total DMI was higher $(\mathrm{P}<0.001)$ in supplemented treatments than control ones. Whereas, the total DMI was higher $(\mathrm{P}<0.001)$ in the order of $\mathrm{T} 2>\mathrm{T} 3>\mathrm{T} 4>\mathrm{T} 5>\mathrm{T} 1$. The CP intake was higher $(\mathrm{P}<0.001)$ in the order $\mathrm{T} 2>\mathrm{T} 3>\mathrm{T} 4>\mathrm{T} 5>\mathrm{T} 1$. Sheep fed on grass hay alone had higher $(\mathrm{P}<0.001) \mathrm{NDF}$ and ADF intake compared with those supplemented ones.

\section{Body Weight Change}

The final BW, BW change and Daily BW gain were higher $(\mathrm{P}<0.001)$ in sheep than the control group (Table 04). Sheep fed non-supplemented diet lost body weight by of $7.2 \mathrm{~g} /$ day. Among the supplemented dietary group, the daily BW gain, BW change, and final BW was better $(\mathrm{P}<0.001)$ in the order $\mathrm{T} 2>\mathrm{T} 3>\mathrm{T} 4>\mathrm{T} 5$. Hiher $(\mathrm{P}<0.05)$ FCE was recorded in sheep fed on $\mathrm{T} 2$ followed by $\mathrm{T} 3$, but similar FCE was documented in sheep ed T4 and T45

Table 02: Chemical composition of experimental feed

\begin{tabular}{cccccc}
\hline \multirow{2}{*}{ Offered } & \multicolumn{5}{c}{ g/kg DM } \\
\cline { 2 - 6 } & Grass Hay & MSLM & 2:1MSLM WB & $1: 2$ MSLM WB & WB \\
\hline DM & 905.2 & 895.7 & 896.9 & 901.7 & 899.8 \\
OM & 927.4 & 876.2 & 870.5 & 879.3 & 884.5 \\
Ash & 69.1 & 96.5 & 78.2 & 45.8 & 39.4 \\
CP & 52.7 & 283.8 & 221.4 & 194.6 & 172.9 \\
NDF & 634.3 & 134.3 & 155.9 & 169.2 & 189.2 \\
ADF & 471.9 & 125.3 & 180.7 & 133.4 & 138.1 \\
ADL & 78.4 & 40.6 & 35.3 & 50.7 & 69.2 \\
\hline Hay Refusal & $(\mathrm{T} 1)$ & $(\mathrm{T} 2)$ & $(\mathrm{T} 3)$ & $(\mathrm{T} 4)$ & $(\mathrm{T} 5)$ \\
\hline DM & 890.4 & 903.1 & 905.8 & 910.2 & 904.6 \\
OM & 945.8 & 890.2 & 887.4 & 891 & 890.8 \\
Ash & 82.7 & 104.9 & 83.1 & 55.5 & 50.7 \\
CP & 35.3 & 142.1 & 111.7 & 70.3 & 52.5 \\
NDF & 721.6 & 139.5 & 162. & 178.1 & 195.7 \\
ADF & 496.1 & 210.9 & 192.5 & 148.4 & 140.6 \\
ADL & 80.4. & 50.5 & 53.9 & 64.8 & 72.8 \\
\hline
\end{tabular}

DM: dry matter; OM: organic matter; CP: crude protein; NDF: neutral detergent fiber; ADF: Acid detergent fiber; ADL: acid detergent lignin; MSLM: Moringa stenopetala leaf meal; WB: wheat bran; MSLM WB: mixture of Moringa stenopetala leaf meal and wheat bran. T1: adibitum grass hay; T2: adibitum grass hay + 300g DM MSLM; T3: adibitum grass hay + 200g DM MSLM + 100g DM WB; T4: adlibitum grass hay + 100 g DM MSLM + 200g DM WB; T5: adibitum grass hay + 300g DM WB. 
Table 03: Daily feed intake of Adilo sheep fed basal diet of grass hay and supplemented with different levels of concentrate mix.

\begin{tabular}{cccccccc}
\hline \multirow{2}{*}{$\begin{array}{c}\text { Feed intake } \\
\text { (g/head/d })\end{array}$} & $\mathrm{T} 1$ & $\mathrm{~T} 2$ & $\mathrm{~T} 3$ & $\mathrm{~T} 4$ & $\mathrm{~T} 5$ & SEM & Significance \\
\cline { 2 - 8 } & $523.2^{\mathrm{a}}$ & $446.3^{\mathrm{b}}$ & $438.5^{\mathrm{c}}$ & $431.9^{\mathrm{d}}$ & $418.6^{\mathrm{e}}$ & 26.52 & $* * *$ \\
Hay DMI & - & 300 & 300 & 300 & 300 & 0.00 & - \\
Concentrate DMI & $523.2^{\mathrm{e}}$ & $746.3^{\mathrm{a}}$ & $738.5^{\mathrm{b}}$ & $731.9^{\mathrm{c}}$ & $718.6^{\mathrm{d}}$ & 24.07 & $* * *$ \\
Total DMI & $435.8^{\mathrm{b}}$ & $581.2^{\mathrm{a}}$ & $615.6^{\mathrm{a}}$ & $590.3^{\mathrm{a}}$ & $585.1^{\mathrm{a}}$ & 22.02 & $* * *$ \\
Total OMI & $21.2^{\mathrm{e}}$ & $58.4^{\mathrm{a}}$ & $60.1^{\mathrm{b}}$ & $53.9^{\mathrm{c}}$ & $49.6^{\mathrm{d}}$ & 5.20 & $* * *$ \\
Total CPI & $490.6^{\mathrm{a}}$ & $353.2^{\mathrm{c}}$ & $364.3^{\mathrm{b}}$ & $390.4^{\mathrm{ab}}$ & $434.6^{\mathrm{b}}$ & 19.74 & $* * *$ \\
Total NDFI & $184.3^{\mathrm{a}}$ & $137.4^{\mathrm{c}}$ & $140.3^{\mathrm{b}}$ & $162.3^{\mathrm{ab}}$ & $169.9^{\mathrm{ab}}$ & 10.37 & $* * *$ \\
Total ADFI & & & & & & & \\
\hline
\end{tabular}

$a, b, c, d, \mathrm{e}$ Means within rows having different superscript are significantly different $* * * \mathrm{P}<0.001$; DMI: dry matter intake; OMI: organic matter intake; CPI: crude protein intake; NDF; neutral detergent fiber intake; ADF: acid detergent fiber; SEM: pooled standard error mean. T1: adibitum grass hay; T2: adibitum grass hay + 300g DM MSLM; T3: adibitum grass hay + 200g DM MSLM + 100g DM WB; T4: adibitum grass hay + 100g DM MSLM + 200g DM WB; T5: adibitum grass hay + 300g DM WB.

Table 04: Body weight change of Adilo sheep fed grass hay and supplemented with different forms of concentrate mix.

\begin{tabular}{cccccccc}
\hline Measurement Variables & T1 & T2 & T3 & T4 & T5 & SEM & P - value \\
\hline $\begin{array}{c}\text { Initial Body weight } \\
(\mathrm{kg})\end{array}$ & $18.5^{\mathrm{a}}$ & $17^{\mathrm{e}}$ & $18^{\mathrm{b}}$ & $17.2^{\mathrm{d}}$ & $17.5^{\mathrm{c}}$ & 0.27 & $<0.01$ \\
$\begin{array}{c}\text { Final Body weight } \\
(\mathrm{kg})\end{array}$ & $17.8^{\mathrm{e}}$ & $23.4^{\mathrm{a}}$ & $22.6^{\mathrm{b}}$ & $21.2^{\mathrm{c}}$ & $20.5^{\mathrm{d}}$ & 0.91 & $<0.01$ \\
$\begin{array}{c}\text { Body weight change } \\
(\mathrm{kg})\end{array}$ & $0.7^{\mathrm{d}}$ & $6.4^{\mathrm{a}}$ & $4.6^{\mathrm{b}}$ & $4.2^{\mathrm{c}}$ & $4.0^{\mathrm{c}}$ & 1.08 & $<0.05$ \\
$\begin{array}{c}\text { Average daily body weight gain } \\
(\mathrm{g})\end{array}$ & $-7.8^{\mathrm{e}}$ & $71.1^{\mathrm{a}}$ & $51.1^{\mathrm{b}}$ & $46.7^{\mathrm{c}}$ & $44.4^{\mathrm{d}}$ & 10.8 & $<0.01$ \\
$\begin{array}{c}\text { Feed Conversation Efficiency } \\
(\text { FCE) }\end{array}$ & $-0.015^{\mathrm{d}}$ & $0.095^{\mathrm{a}}$ & $0.069^{\mathrm{b}}$ & $0.064^{\mathrm{c}}$ & $0.062^{\mathrm{c}}$ & 0.01 & $<0.05$ \\
\hline
\end{tabular}

${ }_{a, b, c, d}$ Means with different superscript in the row are different $\mathrm{p}<0.01(* *)$; SEM: pooled standard error of mean. T1: adibitum grass hay; T2: adibitum grass hay + 300g DM MSLM; T3: adibitum grass hay + 200g DM MSLM + 100g DM WB; T4: adibitum grass hay + 100 g DM MSLM + 200 g DM WB; T5: adibitum grass hay + 300g DM WB.

\section{Nutrient Digestibility}

The digestibility of DM, OM, CP, NDF and ADF were significantly higher $(\mathrm{P}<0.05)$ for sheep in the supplemented group than nonsupplemented group (Table 05). In the current study, the apparent digestibility of DM and $\mathrm{CP}$ were statistically higher $(\mathrm{P}<0.05)$ in the supplemented sheep than to non-supplement once. Among the supplement group, $\mathrm{CP}$ was higher digestibility were higher $(\mathrm{P}<0.05)$ in $\mathrm{T} 2$ followed by $\mathrm{T} 3$, but there were no significance $(\mathrm{P}<0.05)$ between $\mathrm{T} 4$ and T5. However, the apparent digestibility of OM, NDF and ADF was not significantly different $(p>0.05)$ among the supplemented treatments. 
Table 05: Apparent digestibility of nutrients in Adilo sheep fed grass hay-based diet and supplemented with different levels of concentrate mix.

\begin{tabular}{cccccccc}
\hline $\begin{array}{c}\text { Apparent } \\
\text { Digestibility (\%) }\end{array}$ & T1 & T2 & T3 & T4 & T5 & SEM & P - value \\
\hline DM & $53.9^{\mathrm{d}}$ & $68.9^{\mathrm{a}}$ & $66.4^{\mathrm{b}}$ & $63.7^{\mathrm{b}}$ & $60.2^{\mathrm{c}}$ & 1.33 & $<0.05$ \\
OM & $56.3^{\mathrm{b}}$ & $69.6^{\mathrm{a}}$ & $69.5^{\mathrm{a}}$ & $69.8^{\mathrm{a}}$ & $70.4^{\mathrm{a}}$ & 2.4 & $\geq 0.05$ \\
CP & $71.6^{\mathrm{d}}$ & $91.3^{\mathrm{a}}$ & $87.7^{\mathrm{b}}$ & $84.1^{\mathrm{b}}$ & $82.6^{\mathrm{c}}$ & 2.89 & $<0.05$ \\
NDF & $61.6^{\mathrm{b}}$ & $64.1^{\mathrm{a}}$ & $63.9^{\mathrm{a}}$ & $63.8^{\mathrm{a}}$ & $63.5^{\mathrm{a}}$ & 0.59 & $\geq 0.05$ \\
ADF & $51.6^{\mathrm{b}}$ & $59.7^{\mathrm{a}}$ & $59.9^{\mathrm{a}}$ & $59.3^{\mathrm{a}}$ & $59.1^{\mathrm{a}}$ & 1.44 & $\geq 0.05$ \\
\hline
\end{tabular}

a,b,c,d Means within the same rows not bearing a common superscript differ significantly at $P<0.001$; NS: non-significant; DM: dry matter; OM: organic matter; CP: crude protein; NDF: neutral detergent fiber; ADF: acid detergent fiber. T1: adibitum grass hay; T2: adibitum grass hay + 300g DM MSLM; T3: adibitum grass hay + 200g DM MSLM + 100g DM WB; T4: adibitum grass hay + 100g DM MSLM + 200g DM WB; T5: adibitum grass hay + 300g DM WB.

\section{DISCUSSION}

As illustrated in Table 2, the DM, OM, ash, CP, $\mathrm{NDF}, \mathrm{ADF}$ and ADL content of grass hay were $905.2 \mathrm{~g} / \mathrm{kg} \mathrm{DM}, 927.4 \mathrm{~g} / \mathrm{kg} \mathrm{DM}, 69.1 \mathrm{~g} / \mathrm{kg} \mathrm{DM}$, $52.7 \mathrm{~g} / \mathrm{kg} \mathrm{DM}, 634.3 \mathrm{~g} / \mathrm{kg} \mathrm{DM}, 471.9 \mathrm{~g} / \mathrm{kg} \mathrm{DM}$, and $78.4 \mathrm{~g} / \mathrm{kg} \mathrm{DM}$, respectively. Accordingly, the DM content of grass hay was in agreement with the value $914 \mathrm{~g} / \mathrm{kg}$ obtained by Bishaw and Melaku (2009) but higher than the values reported by Zemichael (2007) (881.4 g/kg DM) and Fitwi and Taddesse (2013) (886 g/kg). This higher DM content of grass hay might be due to maturity at harvest and proper drying (Feyera and Animut, 2011).

The NDF component of hay used in the current study was lower compared to the result (756.8 and $767.5 \mathrm{~g} / \mathrm{kg} \mathrm{DM})$ reported by Dessie et al. (2010) and Bishaw and Melaku (2009), respectively. The ADF content of hay obtained in this study was in an agreement with $468 \mathrm{~g} / \mathrm{kg}$ DM reported by Abebaw and Solomon (2008), but higher than the value $(445 \mathrm{~g} / \mathrm{kg} \mathrm{DM})$ reported by Tafa et al. (2010) and lower than the value (510 g/kg DM) reported by Dessie et al. (2010). The ADL content of grass hay used in the current study was comparable to the result obtained by Dessie et al. (2010), but higher than 43.6 and $56 \mathrm{~g} / \mathrm{kg}$ DM reported by Tafa et al. (2010) and Bishaw and Melaku (2008), respectively. The difference in the ADL content might be due to the difference in the proportion of grass species and stage of maturity at the harvest. The OM of grass hay in the current study was comparable with the result $(107 \mathrm{~g} / \mathrm{kg})$ reported by Dessie et al. (2010).

The CP content of grass hay was also comparable with the result (51.5, and $56 \mathrm{~g} / \mathrm{kg}$ DM) reported by Nurfeta (2010) and Getachew (2005), respectively. However, CP value obtained from the grass hay is still lower since ruminant animals need 70 to $75 \mathrm{~g} / \mathrm{kg} \mathrm{CP}$ to satisfy maintenance requirement and microbial fermentation (McDonald et al., 2002). Hence, this indicates that there is a need to supplement with good protein sources either from agroindustrial byproducts, fodder trees like Moringa leaf meal and other protein sources. The NDF (cellulose, hemicelluloses and lignin fraction) of grass hay was lower as compare to the value $792 \mathrm{~g} / \mathrm{kg}$ DM reported by Bishaw and Melaku (2008) but higher than $612 \mathrm{~g} / \mathrm{kg}$ DM reported by Feyera and Animut (2011). High NDF content in the diet leads to reduction in DM digestibility (Dessie et al., 2010) and DMI due to slow passage rate.

The CP content of WB was $172.9 \mathrm{~g} / \mathrm{kg} \mathrm{DM}$, which was higher than the values $(160,165$ and $168.2 \mathrm{~g} / \mathrm{kg} \mathrm{DM}$ ) obtained by Feyera and Animut, (2011), Solomon (2004) and Hagos and Melaku (2009), respectively, but lower than 
the value (199.9 $\mathrm{g} / \mathrm{kg} \mathrm{DM})$ reported by Alemu (1981). This difference in CP values obtained by different scholars might be due to the soil type where the wheat had grown, storage and processing techniques in the milling industry (McDonand, 2002). The NDF and ADF of wheat bran in this study were higher to the values of 317 and $94.6 \mathrm{~g} / \mathrm{kg} \mathrm{DM}$, reported by Hagos and Melaku (2009), respectively, but lower than $612 \mathrm{~g} / \mathrm{kg}$ DM reported by Feyera and Animut (2011). The CP content of T1, T2, T3, T4 and T5 was $52.7 \mathrm{~g} / \mathrm{kg} \mathrm{DM}, 283.8 \mathrm{~g} / \mathrm{kg}$ DM, $221.4 \mathrm{~g} / \mathrm{kg} \mathrm{DM}, 194.3 \mathrm{~g} / \mathrm{kg} \mathrm{DM}$ and 172.9 $\mathrm{g} / \mathrm{kg} \mathrm{DM}$, respectively. This indicates that T2 (Moringa stenopetala leaf meal) was higher in $\mathrm{CP}$ content than other treatment feeds. Beside to this, MSLM is found to be a good protein supplement due to its adequate CP content for maintenance and proper function of rumen microbes for efficient utilization of fibrous feed. The CP content of Moringa Stenoptala leaf meal used in the current study was consistent with the result $(282 \mathrm{~g} / \mathrm{kg} \mathrm{DM})$ reported by Melesse et al. (2009), higher than the CP contents (228.5 and $228 \mathrm{~g} / \mathrm{kg} \mathrm{DM}$ ) reported by Jiru et al. (2006), and Sánchez et al. (2006) for Moringa oleifera leaf meal, respectively, but lower than the result (306 and $360 \mathrm{~g} / \mathrm{kg}$ DM) obtained by Melesse (2011) and Negesse et al. (2009), respectively. Beside to good protein supply, MSLM is also a good source of minerals mainly phosphorus, magnesium, potassium and sodium (Melesse, 2011). Furthermore, use of MSLM in animal feed is safe since it contains very low $(<14 \mathrm{~g} /$ $\mathrm{kg} \mathrm{DM}$ ) amount of tannin (Makkar and Becker, 1996; Melesse et al., 2009).

The NDF content obtained of MSLM obtained in this study is comparable with the result (131 and131.8 g/kg DM) reported by Negesse et al. (2009) and Gebregiorgis et al. (2012) respectively. On the other hand, the ADF content is higher than the value (96 and 111.8 $\mathrm{g} / \mathrm{kg} \mathrm{DM}$ ) reported by Negesse et al. (2009) and Gebregiorgis et al. (2012) but lower than the value obtained by Melesse et al. (2008) and Melesse (2011) which is 133 and $142 \mathrm{~g} /$ kg DM, respectively. According to McDonald et al. (2002) feeding with higher NDF and ADF composition is characterized by lower the nutritive value and digestibility.

In the current study, the DM intake of grass hay for Control group (T1) was higher $(523.2 \mathrm{~g} / \mathrm{d})$ than the supplemented sheep which is 446.3 $\mathrm{g} / \mathrm{d}, 438.5 \mathrm{~g} / \mathrm{d}, 431.9 \mathrm{~g} / \mathrm{d}$, and $418.6 \mathrm{~g} / \mathrm{d}$ for T2, T3, T4 and T5, respectively (Table 3). Since sheep in control treatment fed on grass hay alone which is lower in $\mathrm{CP}$ and Energy value so to satisfy their daily nutrient requirement they forced to consume comparatively more grass hay than supplemented ones. The total DMI was lower $(\mathrm{P}<0.001)$ in sheep fed non-supplemented feed than those fed supplemented ones. The high content of cell wall fractions in the hay could result low feed intake due to its effect on degradability and passage rate (McDonald et al., 2002).

The total daily DMI of sheep fed supplemented diets $(718.6-746.2 \mathrm{~g} /$ head/day) in the current study was comparable to $701-730 \mathrm{~g} / \mathrm{head} / \mathrm{day}$ reported for Arsi-Bale sheep supplemented with linseed cake (LSC) and/or wheat bran (Tafa et al., 2010), but lower than 850-914 g/head/ day reported for Horro lambs supplemented with wheat bran, Acacia albide leaf meal or their mixture (Feyera and Animut, 2011). In the current study, concentrate supplementation reduce the total DMI of hay. This could be due to substitution of grass hay by concentrate supplementation. Ibrahim and Tibin (2003) reported that total DMI of the supplemented group is increased due to the higher intake of CP. This is due to the fact that supplementation enhances rumen microbes which could facilitate the rate of digestion. Higher degradability as well as passage rare encourages DMI (McDonald et al., 2002). Moreover, DMI could be improved by dietary protein supplementation (Vansoset, 1994). Among the supplement, the higher DM intake $(\mathrm{P}<0.001)$ in $\mathrm{T} 2$ compare to $\mathrm{T} 3, \mathrm{~T} 4$, and T5 might be due to the relatively higher content of CP and low contents of NDF and ADF. 
Sheep supplemented with T2, T3, T4 and T5 showed significantly higher $(\mathrm{P}<0.001)$ BW gain, final BW and FCE than non-supplemented ones (Table 4). Body weight loss of $7.8 \mathrm{~g} /$ head/day was recorded in sheep fed hey alone. Similar result was reported by Gebregiorgis et al. (2012) in sheep fed Rhodes grass hay based diet. The loss of BW in the current study is comparable with $9.11 \mathrm{~g} / \mathrm{head} /$ day reported by Bishaw and Melaku (2008) in sheep offered grass hay alone, but lower than $19.9 \mathrm{~g} / \mathrm{head} /$ day obtained by Bonsi et al. (1996) in sheep fed tef straw alone, such loss in body weight in the nonsupplemented sheep might be attributed to low $\mathrm{CP}$ intake fed on sole grass hay. Mobilization of body reserve during negative energy balance to meet their nutrient demand for physiological function could also attribute to the loss in body weight (McDonald et al., 2002). On the other hand, the higher BW parameters and FCE in the supplemented sheep could be justified due to the higher total DMI, CP intake and better nutrient digestibility of the treatment feeds. According to Ranjhan (1997), the average digestible crude protein (DCP) requirement of sheep weighing $30 \mathrm{~kg}$ is $36 \mathrm{~g} / \mathrm{head} /$ day. In the present study, the supplemented sheep had DCP /head/day intake of $58.4 \mathrm{~g}, 60.1 \mathrm{~g}, 53.9 \mathrm{~g}$, and $49.6 \mathrm{~g}$ for T2, T3, T4 and T5, respectively were as the nonsupplemented sheep consumed 21.2 g DCP / head/day. This indicated that the supplemented sheep were received DCP above their daily requirement. This might justify for the reason why the supplemented sheep achieved better BW gain. The average BW change, daily gain and final BW were significantly higher $(\mathrm{P}<0.001)$ in sheep supplemented with $\mathrm{T} 2$ compared to all other treatment. This could be attributed due to the higher DM and CP intake. In line with the present study, Hagos and Melaku (2009) and Abebaw and Solomon (2008) found that sheep supplemented with good protein source showed better daily gain and final BW. In the current study, the average daily BW gain in the supplemented sheep were comparable with $43.3-67.1 \mathrm{~g} / \mathrm{head} /$ day reported in Afar rams supplemented with sole noug seed cake, wheat bran, sesame seed cake and their mixture (Hagos and Melaku, 2009).

The DM digestibility of hay used in the current study was comparable to $52.8 \%$ reported by Bishaw and Melaku (2008) and $53 \%$ reported by Tafa et al. (2010), but higher than $25.5 \%$ reported by Gebregiorgis et al. (2012). The apparent DM digestibility of MSLM in the current study was higher than $26.8 \%$ reported by Gebregiorgis et al. (2012) in sheep supplemented with $300 \mathrm{~g}$ MSLM to Rhodes grass hay based diet. The digestibility of DM in WB in this study was $60.2 \%$. Similar result was reported by Tafa et al. (2010) when linseed cake and or wheat bran was supplemented to Arsi-Bale sheep fed grass hay. In the current study, the higer apparent digestibility of DM and CP could be attributed to higher protein and lower fiber content of the supplement diets. Similarly, improvement in digestibility as a result of increasing dietary $\mathrm{CP}$ content was recorded by Mulligan et al. (2001). On the other hand, the lower DM, OM and CP digestibility recoded in the non-supplemented sheep could be justified by the lower amount CP intake which might restrict nitrogen supply to fiber or starch digesting microbes to optimize the feed digestion efficiency. Similarly, Ranjhan (1997) point out that supplementation of protein rich diets to low protein roughage diet increase rumen microbial population as a result the degradation of fibrous feed in rumen enhanced vigorously. The $\mathrm{DM}, \mathrm{OM}$ and $\mathrm{CP}$ digestibility of MSLM and WB when fed in mixture were comparatively higher than WB alone. This might be due to associative effect (McDonanld et al., 2002). The finding of the current study is in agreement with Feyera and Animut (2011). Similar result were also reported by Simret (2005), Gebru (2009) and Feyera and Animut (2011).

\section{CONCLUSIONS}

Based on the results of the current study, sheep fed on control treatment showed the lowest 
total DMI, apparent nutrient digestibility with BW loss, while sheep fed supplemented diets containing 300g DM sole MSLM, 2MSLM:1WB mix, 1MSLM:2WB mix and sole WB in Rhodes grass hay-based diets promoted total DMI, nutrient digestibility and BW gain. Among the supplemented dietary groups, significantly higher daily BW gain, final BW and FCE were recorded in sheep fed sole MSLM. Therefore, supplementation with sole MSLM could be recommended for sheep producers to get better nutrient utilization and growth performance.

\section{REFERENCES}

Abebaw N. and Solomon M . (2008). Feed intake, digestibility and body weight change in Farta sheep fed hay supplemented with rice bran and/or noug seed (Guizotia abyssinica) meal. Tropical Animal Health Production. 41: 507-515. DOI: http://dx.doi.org/10.1007/s11250008-9215-5

Alemu Y. (1981). Laboratory evaluation and nutritive value of some feedstuffs produced in the Alemaya Woreda. MSc Thesis Presented to the School of Graduate Studies of Addis Ababa University, Collage of Agriculture, Alemaya, Ethiopia. Pp82. DOI: http://dx.doi.org/10.3934/ energy.2017.4.667

AOAC (1990). Official Methods of Analysis 15th ed. Association of Official Analytic Chemists. AOAC. (Arlington, USA). DOI: http://dx.doi.org/10.1002/0471740039.vec0284

Bake, W and M.R. Hansen (1987). Seasonal diets of camels, cattle, sheep and goats in a common range in Eastern Africa. Journal of Range Management. 76-79. DOI: http://dx.doi. org/10.2307/3899366

Bishaw, F., \& Melaku, S. (2008). Effects of supplementation of Farta sheep fed hay with sole or Mixtures of noug seed meal and wheat bran on feed intake, digestibility and body weight change. Tropical Animal Health and Production, 40(8), 597-606. DOI: http://dx.doi. org/10.1007/s11250-008-9138-1

Bonsi, M.L.K., A.K. Tuah, P.O. Osuji, V.I. Nsahlai and N.N. Umunna (1996). The effect of protein supplement sources or supply pattern on the intake, digestibility, rumen kinetics, nitrogen utilization and growth of Ethiopian Menze sheep fed tefff straw. Animal Feed Science and Technology. 64: 11-25. DOI: http://dx.doi.org/10.1016/s0377-8401(96)01048-6

CSA (Central statistics Authority) (2011). Federal Republic of Ethiopia Agricultural sample survey. Report on Livestock characteristics. Addis Ababa, Ethiopia. DOI: http://dx.doi.org/10.3934/ energy.2017.4.667

CTA Tropical Agriculture (1991). Sheep. Rene.coste (9 $9^{\text {th }}$ edition), McMillan press. (UK).PP.1-50. DOI: http://dx.doi.org/10.1017/s0266467400006374

Dessie, J., Melaku, S., Tegegne, F., \& Peters, K. J. (2010). Effect of supplementation of Simada sheep with graded levels of concentrate meal on feed intake, digestibility and body-weight parameters. Tropical animal health and production, 42(5), 841-848. DOI: http://dx.doi. org/10.1007/s11250-009-9496-3 
Feyera, T., \& Animut, G. (2011). Digestion, intake and live weight changes of Horro lambs fed vetch (Lathyrus sativus) haulm basal diet supplemented with sole wheat bran, Acacia albida leaf meal or their mixture. Pakistan Journal of Nutrition, 10(11), 1013-1021. DOI: http:// dx.doi.org/10.3923/pjn.2011.1013.1021

Fitwi, M., \& Tadesse, G. (2013). Effect of sesame cake supplementation on feed intake, body weight gain, feed conversion efficiency and carcass parameters in the ration of sheep fed on wheat bran and teff (Eragrostis teff) straw. Momona Ethiopian Journal of Science, 5(1), 89106. DOI: http://dx.doi.org/10.4314/eajsci.v3i1.42784

Gebregiorgis, F., Negesse, T., \& Nurfeta, A. (2012). Feed intake and utilization in sheep fed graded levels of dried moringa (Moringa stenopetala) leaf as a supplement to Rhodes grass hay. Tropical Animal Health and Production, 44(3), 511-517. DOI: http://dx.doi.org/10.1007/ s11250-011-9927-9

Gebru T. (2009). Supplementation with different forms of lupin (Lupinus albus) grain in hay based feeding of washera sheep: Effect on feed intake, digestibility body weight and carcass parameter. M.Sc. Theses presented to School of Graduate Study, Haramaya University. DOI: http://dx.doi.org/10.1007/s11250-015-0901-9

Getachew A. (2005). Evaluation of forage yield and effect of forms of feeding of Acacia salignia on intake and live weight gain of Farta sheep fed on grass hay. M.Sc. thesis Alemaya University (present Haramaya University). Alemeya, Ethiopia. DOI: http://dx.doi.org/10.1016/j. anifeedsci.2009.05.010

Hagos, T., \& Melaku, S. (2009). Feed intake, digestibility, body weight and carcass parameters of Afar rams fed tef (Eragrostis tef) straw supplemented with graded levels of concentrate mix. Tropical Animal Health and Production, 41(4), 599-606. DOI: http://dx.doi.org/10.1007/ s11250-008-9230-6

Ibrahim, A., \& Tibin, I. M. (2003). Feeding potential of Faidherbia albida ripe pods for Sudan desert goats. Sci. J. King Faisal University, 4(1), 137-144. DOI: http://dx.doi.org/10.4314/ jard.v2i1.42196

ILCA (International Livestock Centre for Africa) (1988). Livestock System research Manual, ILCA Working Paper, No. 1. Vol.1 International Livestock Centre for Africa (ILCA), Addis Ababa, Ethiopia. DOI: http://dx.doi.org/10.1016/0167-5877(84)90043-6

Jiru, D., Sonder, K., Alemayehu, L., Mekonen, Y., \& Anjulo, A. (2006). Leaf yield and nutritive value of Moringa stenopetala and Moringa oleifera accessions: its potential role in food security in constrained dry farming agroforestry system. Proceedings on Moringa and Other Highly Nutritious Plant Resources: Strategies, Standards and Markets for a Better Impact on Nutrition in Africa. Accra, Ghana. DOI: http://dx.doi.org/10.1007/s10457-013-9626-9

Makkar, H.P.S. and Becker, K.. (1996). Nutrional value and antinutritional components of whole and ethanol extracted Moringa oleifera leaves. Animal feed science and technology, 63(1-4). 211-228. DOI: http://dx.doi.org/10.1016/s0377-8401(96)01023-1 
Markos T. (2006). Productivity and Health of indigenous sheep breeds and cross breeds in the central Ethiopian Highlands. PhD Thesis presented to Swedish University of Agricultural Science, Uppsala. 4P. DOI: http://dx.doi.org/10.1016/0301-6226(96)82465-1

McDonald, P., R.A. Edward, J.F.D. Greenhalgh and G.A. Morgan. (2002). Animal Nutrition $6^{\text {th }}$ ed. Pearson Educational Limited. Edinburgh, Great Britain. Pp 544. DOI: http://dx.doi. org/10.1017/s0014479700021918

Melesse,A. (2011). Comparative assessment on chemical compositions and feeding values of leaves of Moringa stenopetala and Moringa oleifera using in vitro gas production method. Journal of Applied Science Technology, 2(2), 31-41. DOI: http://dx.doi.org/10.5897/ajb11.4180

Melesse, A., Bulang, M., Kluth, H. (2009). Evaluating the nutritive values and in vitro degradability characteristics of leaves, seeds and seedpods from Moringa stenopetala. Journal of the Science of Food and Agriculture, 89, 281-287. DOI: http://dx.doi.org/10.1002/jsfa.3439

Mulligan, F.J., Caffrey, P.J., Rath, M., Kenny, M.J. and O'mara, F.P. (2001). The effect of dietary protein content and hay intake level on the true and apparent digestibility of hay. Livestock Production Science. 68, 41-52. DOI: http://dx.doi.org/10.1016/s0301-6226(00)00209-8

Nega, A. and Melaku, S. (2009). Feed intake, digestibility and bodyweight change in Farta sheep fed hay supplemented with rice bran and/ or noug seed (Guizotia abyssinica) meal. Tropical Animal Health and Production, 41, 507-515. DOI: http://dx.doi.org/10.1007/s11250-0089215-5

Negesse T., Makkar H.P.S., Becker K. (2009). Nutritive value of some non-conventional feed resources of Ethiopia determined by chemical analyses and an in vitro gas method. Anim. Feed Science Technology. 154, 204-217. DOI: http://dx.doi.org/10.1016/j.anifeedsci.2009.09.010

Nurfeta, A. (2010). Feed intake, digestibility, nitrogen utilization and body weight change of sheep consuming wheat straw supplemented with local agricultural and agro-industrial by-products. Tropical Animal Health and Production, 42, 815-824. DOI: http://dx.doi. org/10.1007/s11250-009-9491-8

Ranjhan, S.K. (1997). Animal nutrition in the tropics $4^{\text {th }}$ (edition), vikas publishing house PVT (TD). Pp. 554. DOI: http://dx.doi.org/10.1002/pad.4230050215

SAS (Statistical Analysis System) (2004). Ver. 9.0. SAS Institute Inc. Cary North California, USA. DOI: http://dx.doi.org/10.1177/0894439314544925

Simret B. (2005). Supplementation of graded levels of peanut cake and wheat bran mixture on nutrient utilization and carcass parameters of Somali goats. M.Sc. Thesis Presented to the School of Graduate Studies of Alemaya University of Agriculture, Alemaya, Ethiopia. Pp. 60. DOI: http://dx.doi.org/10.1007/s11250-008-9133-6

Solomon M. (2004). Feed intake, digestion kinetics and rumen volatile fatty acids in Menz rams supplemented with Lablab purpureus or graded levels of Leucaena pallid 14203 and sesbania sesban 1198. Animal Feed Science and Technology.117:61-73. DOI: http://dx.doi. org/10.1016/j.anifeedsci.2004.07.016 
Tafa, A., Melaku, S., \& Peters, K. J. (2010). Supplementation with linseed (Linum usitatissimum) cake and/or wheat bran on feed utilization and carcass characteristics of Arsi-Bale sheep. Tropical animal health and production, 42(4), 677-685. DOI: http://dx.doi.org/10.1007/ s11250-009-9475-8

Van Soest P.J. (1994). Nutritional Ecology of the Ruminant. Cornell university press, Ithaca and London.pp.476. DOI: http://dx.doi.org/10.2307/2273176

Zemicael G. (2007). Supplementation of sesame seed (Sesame indicum) cake, wheat bran and their mixtures on feed intake, digestibility, live weight changes and carcass characteristics of Arado sheep fed a basal diet of teff straw. An MSc Thesis Presented to the School of Graduate Studies of Alemaya University of Agriculture, Ethiopia. DOI: http://dx.doi.org/10.4314/ eajsci.v3i1.42784 